\title{
Optimising Operational Reliability and Performance in Aerobic Passive Mine Water Treatment: the Multistage Westfield Pilot Plant
}

\author{
Joscha Opitz $[$ Martin Bauer · Jutta Eckert • \\ Stefan Peiffer $\cdot$ Matthias Alte
}

Received: 25 October 2021 / Accepted: 3 February 2022 / Published online: 12 February 2022

(C) The Author(s) 2022

\begin{abstract}
A three-stage pilot system was implemented for passive treatment of circumneutral, ferruginous seepage water at a former opencast lignite mine in southeast Germany. The pilot system consisted of consecutive, increasingly efficient treatment stages with settling ponds for pretreatment, surface-flow wetlands for polishing and sediment filters for purification. The overall objective of the multistage approach was to demonstrate applicability and operational reliability for successive removal of iron as the primary contaminant broadly following Pareto's principle in due consideration of the strict site-specific effluent limit of $1 \mathrm{mg} / \mathrm{L}$. Average inflow total iron concentration was $8.4( \pm 2.4) \mathrm{mg} / \mathrm{L}$, and effluent concentration averaged $0.21( \pm 0.07) \mathrm{mg} / \mathrm{L}$. The bulk iron load $(\approx 69 \%)$ was retained in settling ponds, thus effectively protecting wetlands and sediment filter from overloading. In turn,
\end{abstract}

Supplementary Information The online version contains supplementary material available at https://doi. org/10.1007/s11270-022-05538-4.

J. Opitz $(\bowtie) \cdot$ J. Eckert · S. Peiffer

BayCEER, Department of Hydrology, University

of Bayreuth, Universitätsstraße 30, 95447 Bayreuth,

Germany

e-mail: joscha.opitz@uni-bayreuth.de

J. Opitz $\cdot$ M. Bauer $\cdot$ M. Alte

BASE TECHNOLOGIES GmbH, Josef-Felder-Straße 53,

81241 Munich, Germany wetlands and sediment filters displayed similar discrete treatment efficiency ( $\approx 73 \%$ each) relative to settling ponds and thus proved indispensable to reliably meet regulatory requirements. Moreover, the wetlands were found to additionally stimulate and enhance biogeochemical processes that facilitated effective removal of secondary contaminants such as $\mathrm{Mn}$ and $\mathrm{NH}_{4}$. The sediment filters were found to reliably polish particulate and redox-sensitive compounds ( $\mathrm{Fe}, \mathrm{As}, \mathrm{Mn}, \mathrm{NH}_{4}, \mathrm{TSS}$ ) whilst concomitantly mitigating natural spatiotemporal fluctuations that inevitably arise in open systems. Both treatment performance and operational reliability of the multistage pilot system were comparable to the conventional treatment plant currently operated on site. Altogether the study fully confirmed suitability of the multistage passive setup as a long-term alternative for seepage water treatment on site and provided new insights into the performance and interrelation of consecutive treatment stages. Most importantly, it was demonstrated that strategically combining increasingly efficient components may be used for optimisation of treatment performance and operational reliability whilst providing an opportunity to minimise land consumption and overall costs.

Keywords Constructed wetland $\cdot$ Settling pond . Iron removal · Manganese removal · Nitrification 


\section{Introduction}

Passive treatment is a rapidly spreading, eco-technological approach for the removal of various organic and inorganic contaminants from wastewaters through exploitation and amplification of natural biogeochemical and physical processes (Kadlec \& Wallace, 2009; Vymazal, 2014). In the mining industry, passive technologies are increasingly used for economic and resource-conserving treatment of acidic and/or metalliferous mine water (e.g. Hedin et al., 1994; Skousen et al., 2017; Younger, 2000a). This study is focussed on aerobic surface-flow systems that are commonly used for passive removal of hydrolysable metals $(\mathrm{Fe}$, $\mathrm{Al}, \mathrm{Mn}$ ) from circumneutral, primarily ferruginous mine water (Sapsford, 2013; Wildemann et al., 1993). Aerobic systems predominantly include classic water treatment components such as aeration cascades, settling ponds, surface-flow wetlands and oxic sediment filters or leach beds where contaminant removal and water quality improvement are governed by naturally occurring physical and biogeochemical processes (Skousen et al., 2017).

Trivalent $\mathrm{Fe}$ and $\mathrm{Al}$ readily precipitate at circumneutral $\mathrm{pH}$, forming particulate (oxy)hydroxides (Stumm \& Morgan, 1996) that are subsequently removed through gravitational sedimentation and/ or filtration in settling ponds and wetlands, respectively (Hedin, 2008). In contrast, Mn(II) oxidation and $\mathrm{Mn}(\mathrm{III} / \mathrm{IV})$ precipitation in aerobic passive systems are relatively low unless ameliorated in a favourable environment that promotes distribution of Mn-oxidising bacteria and concomitant formation of (auto)catalytic surfaces (e.g. Luan et al., 2012; Neculita \& Rosa, 2019; Tan et al., 2010; Tebo et al., 2004). Therefore, Mn removal from mine water is commonly promoted in limestone drains/beds (e.g. Christenson et al., 2019; Silva et al., 2010) or low-flow wetlands, the latter potentially amended with organic or limestone-based substrates (e.g. Batty et al., 2008; Hallberg \& Johnson, 2005; Stark et al., 1996). Removal of additional mining-associated metal(loid)s (e.g. As, $\mathrm{Cd}, \mathrm{Cu}, \mathrm{Ni}, \mathrm{Pb}, \mathrm{Zn}$ ) is frequently observed in aerobic passive systems, although it is important to note that this is predominantly attributable to either adsorption and complexation in wetland substrates (Opitz et al., 2021; Sobolewski, 1999) or to the omnipresence of $\mathrm{Fe} / \mathrm{Al} / \mathrm{Mn}$ (oxyhydr)oxides through scavenging, (ad) sorption or co-precipitation (Burrows et al., 2017;
Schaider et al., 2014; Zänker et al., 2003). Beyond that, aerobic passive systems may contribute to biotransformation and decomposition of organic and particularly nitrogen compounds that originate from the use of explosives and extraction chemicals (Johnson, 2015) or as coalification by-products (Chlot et al., 2011). Most notably, elevated $\mathrm{NH}_{4}$ levels in mine waters may be mitigated in aerobic passive systems through nitrification and assimilation by hydrophytes in surface-flow wetlands (Demin et al., 2002; Etteib et al., 2021; Vymazal, 2013). Surface-flow ponds and oxic filter beds further improve basic water quality criteria such as oxygen concentration, redoxpotential, total suspended solids (TSS) and turbidity (García et al., 2003; Kadlec \& Wallace, 2009).

Compared to conventional treatment plants, passive systems are open to environmental influences such as wind, precipitation, evapotranspiration, temperature variation and biological activity that unavoidably result in higher performance fluctuation (Kadlec et al., 2000; Mitsch et al., 2012). Such effects depend, however, on the nature and magnitude of the underlying treatment mechanisms and may thus vary between different mine sites and contaminants with, for instance, biogeochemical processes more susceptible to seasonal variation compared to physicochemical processes (Gu et al., 2006; Opitz et al., 2021). At worst, seasonal variation of water chemistry, temperature or biomass may even result in re-mobilisation of contaminants from wetlands as reported by Goulet and Pick (2001). Therefore, the planning and permission of passive mine water treatment systems requires a thorough decision process in due consideration of the expectable treatment efficiency, operational reliability and environmental impact as well as investment and operating costs, land consumption and at times secondary factors such as waste disposal, site-specific regulatory requirements and ecosystem services (Eppink et al., 2020; Ziemkiewicz et al., 2003). The weighing between passive and conventional treatment may be further complicated by high or fluctuating pollutant loading, spatial restrictions on site, secondary contaminants or site-specific legal and other (environmental) requirements (Trumm, 2010). Whereas hundreds of passive systems were implemented particularly in the Anglo-American area despite initial scepticism as noted by Kleinmann et al. (2021), application of passive technologies for mine water treatment in Germany is still in its infancy, 
which is why both operators and regulators also face a lack of successful domestic showcases as well as a standardised technical and legal basis of valuation.

This study reports on a three-stage pilot plant that was implemented for passive treatment of circumneutral, mining-influenced seepage water at a former lignite open pit in southeast Germany. As opposed to the numerous previous (pilot) studies on passive treatment, the novel pilot system in this study was designed with three consecutive, increasingly efficient treatment stages to increase overall treatment performance and operational reliability. The main objectives of the pilot plant were to (1) demonstrate operational reliability for passive treatment in due consideration of the strict, site-specific discharge limit, (2) assess the multistage setup according to efficacy and limitations of the consecutive treatment stages and (3) generate a database for well-founded upscaling of the pilot plant to full scale. Preliminary results were reported for $\mathrm{Fe}$ as the primary contaminant at the study site, showing effective Fe removal in the pilot system (Opitz et al., 2019). This study investigates the interrelationship and individual contribution of the three consecutive treatment stages for removal of relevant contaminants over the entire 452-day study period. To further assess the suitability of passive treatment for the study site, the treatment performance of the pilot system is ancillary compared to the long-term performance of the conventional treatment plant currently operated on site. The overall objective of this study is to evaluate the conceptual multistage approach for optimising operational reliability and performance of passive mine water treatment systems.

\section{Study Site}

The study site is located near Wackersdorf in the former lignite district of Upper Palatinate in southeast Germany (Fig. 1a). Industrial-scale mining in the Wackersdorf area ceased in 1982, and the postmining landscape is currently in an advanced stage of rehabilitation. Progressing oxidation of sulphide minerals in the backfilled pits results in extensive formation of acid mine drainage (AMD) in the post-mining landscape (Evangelou \& Zhang, 1995).

The Westfield is an opencast segment in the southern Upper Palatine district (Fig. 1b). Two major lignite seems were mined in the Westfield between 1941 and 1982, and parts of the pit were concurrently backfilled with waste rock and ashes from the nearby lignite-fired power plant. In 1984 , the northern $\approx 51.5$ ha of the Westfield pit were approved as a landfill for combustion residues under waste law (Fig. 1c). An estimated $3.1 \times 10^{6} \mathrm{~m}^{3}$ bottom and electrostatic

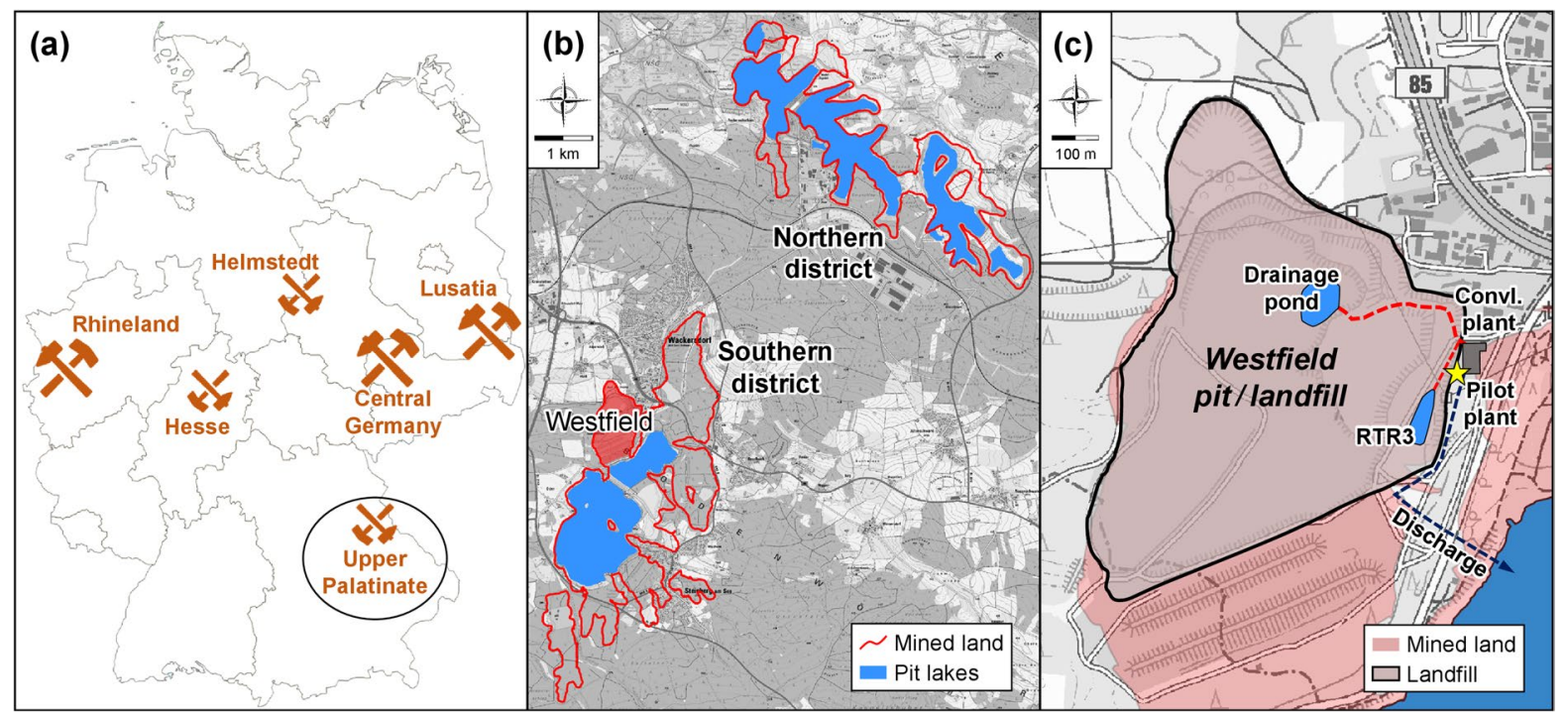

Fig. 1 Geographic location: (a) Germany's lignite mining regions, (b) the historic Upper Palatine lignite district and (c) the Westfield project site (modified maps (C) BayernAtlas 2021) 
Table 1 Raw water chemistry of the conventional Westfield treatment plant 20112021 $(n=128)$

\begin{tabular}{lll}
\hline Parameter & & Lower to upper quartiles \\
\hline $\mathrm{EC}$ & {$[\mathrm{mS} / \mathrm{cm}]$} & $2.7-3.0$ \\
$\mathrm{pH}$ & {$[-]$} & $7.2-7.5$ \\
$\mathrm{Fe}^{1}$ & {$[\mathrm{mg} / \mathrm{L}]$} & $5.0-12.0$ \\
$\mathrm{Al}$ & {$[\mathrm{mg} / \mathrm{L}]$} & $0.1-0.3$ \\
$\mathrm{Mn}$ & {$[\mathrm{mg} / \mathrm{L}]$} & $1.2-1.4$ \\
$\mathrm{Cl}^{2}$ & {$[\mathrm{mg} / \mathrm{L}]$} & $140-245$ \\
$\mathrm{SO}_{4}$ & {$[\mathrm{mg} / \mathrm{L}]$} & $1639-1960$ \\
$\mathrm{Mg}_{\mathrm{Ca}}$ & {$[\mathrm{mg} / \mathrm{L}]$} & $88-113$ \\
$\mathrm{Na}$ & {$[\mathrm{mg} / \mathrm{L}]$} & $554-603$ \\
$\mathrm{~K}$ & {$[\mathrm{mg} / \mathrm{L}]$} & $127-157$ \\
\hline
\end{tabular}

${ }^{1}$ Fe decreased after commissioning of the RTR3 in 2019 owing to intrinsic sedimentation

${ }^{2} \mathrm{Cl}$ steadily dropped from $250-350$ in 2011 to $100-150 \mathrm{mg} / \mathrm{L}$ since 2018 precipitator ash $\left(\approx 4 \times 10^{6} \mathrm{t}\right)$ were deposited in the Westfield landfill until decommissioning in 2003, still leaving a morphological depression behind. Artificial dewatering of the Westfield pit/landfill was maintained for geohydraulic reasons because it was found that groundwater runoff would have affected surrounding aquifer systems and thus threatened regional drinking water resources in the long term. Therefore, seepage water is continually pumped out from a "drainage pond" at the lowest point of the former pit/landfill for protection of adjacent aquifers, thus creating a groundwater drawdown cone that collects ground- and seepage water from the surrounding mined land.

In 1995, a conventional treatment plant was implemented east of the Westfield site for treatment of the ferruginous seepage water. The plant is discontinuously fed from the drainage pond via an intermediate reservoir, the "RTR3", that was commissioned in 2019 (Fig. 1c). Removal of dissolved and particulate $\mathrm{Fe}$ is achieved in a classical physicochemical reactor system through addition of lime slurry for alkalisation followed by addition of flocculants, recycled sludge and flocculant aids. The treated water is discharged to a nearby pit lake. As treatment and discharge of seepage water from the decommissioned landfill were permitted under (waste)water law rather than mining law, a strict site-specific discharge limit for total $\mathrm{Fe}$ of $1 \mathrm{mg} / \mathrm{L}$ was imposed to protect the receiving water.

Groundwater in the mined land surrounding the Westfield is heavily affected by AMD, yet the seepage water leaking in the drainage pond is circumneutral due to the predominantly alkalising character of deposited ashes. The seepage water is mineralised and contaminated with both mining- and ash-typical substances such as $\mathrm{Fe}, \mathrm{Mn}, \mathrm{SO}_{4}, \mathrm{Cl}$ and alkali(ne) earth metals (Table 1). Concentrations of metal(loid)s other than $\mathrm{Fe}$ or $\mathrm{Mn}$ are low despite considerable mobility in the surrounding mined land, which is attributable to the high sorption capacity of the electrostatic precipitator ashes (Mishra \& Tripathi, 2008) and to the circumneutral character of the seepage water where solubility of most metals is low (Stumm $\&$ Morgan, 1996). Seepage water pumped to the conventional treatment plant is thoroughly oxygenated due to the temporary impoundment in drainage pond and RTR3, which is why Fe levels in the raw water are relatively low (Opitz et al., 2020). Temporal fluctuations in seepage water chemistry are attributable to the varying mixing ratio of seepage water, rainwater and surface runoff in drainage pond and RTR3 in consequence of the discontinuous pump operation. Overall, the (geo)technical, hydrogeological and regulatory setup of the Westfield legacy may be unique, especially regarding the artificial water management system.

\section{Materials and Methods}

\subsection{Setup of the Westfield Pilot Plant}

The Westfield pilot plant was implemented in 2017 next to the conventional treatment plant (Fig. 1c). The 
conceptual approach for passive treatment of the mining-influenced seepage water in due consideration of the strict discharge permit criteria was a three-stage system (Fig. 2) for progressing Fe removal broadly following Pareto's principle:

1. Pre-treatment in settling ponds

2. Polishing in surface-flow wetlands

3. Purification in sediment filters

The innovative pilot plant was implemented with three parallel lines. As opposed to most multiline (pilot) systems that were installed to test different materials or setups (e.g. Cravotta \& Trahan, 1999; García et al., 2004; Nyquist \& Greger, 2009; Whitehead \& Prior, 2005), the trifurcated Westfield pilot plant was designed with three identical, parallel lines to generate hydraulic and hydrochemical comparison datasets for investigation of treatment performance, kinetic relationships and critical influencing factors as a basis for upscaling (Opitz et al., 2019).

A large roll-off container $(7.0 \times 2.35 \times 2.25 \mathrm{~m})$ precedes the pilot plant as a distribution "reservoir" that is (discontinuously) filled from the feeding pipe of the conventional plant. Lower roll-off containers $(7.0 \times 2.35 \times 1.25 \mathrm{~m})$ were utilised as settling ponds and wetlands, with all steel containers embedded into the ground for isolation. The wetland containers received a sandy $\approx 0.3$-m substrate layer and were planted with common reed. Lastly, three parallel trenches with approximatively semiellipsoidal cross section (ca. $4.0 \times 0.5 \times 0.25 \mathrm{~m}$ ) were sealed with a plastic liner and filled with granite gravel $(8-16 \mathrm{~mm})$ as sediment filters (Fig. 2a). A total of ten monitoring points (MP01-MP10) for installation of fixed sensors and sampling taps were incorporated into the pipework system in four protected concrete manholes in between treatment stages. The outflow of one component corresponds to the inflow of the subsequent one, with MP01 representing the overall system inflow from the reservoir to the three parallel settling ponds, MP02-MP04 representing settling pond outflows and wetland inflows, MP05-MP07 representing wetland outflows and sediment filter inflows and MP08-MP10 representing sediment filter outflows and thus system effluent (Fig. 2b).

\subsection{Pilot Plant Operation and Hydraulics}

The first months of operation in 2017/2018 were used for vegetational development in wetlands and as a test phase. Following this, the main 452-day study period (July 2018 to December 2019) was commenced where hydraulic loading of the three system lines was varied in four 113-day monitoring periods with a short maintenance break in the summer of 2019. Flow rates in the three system lines were set between 100 and $500 \mathrm{~L} / \mathrm{h}$ each to investigate treatment performance as a function of hydraulic loading.

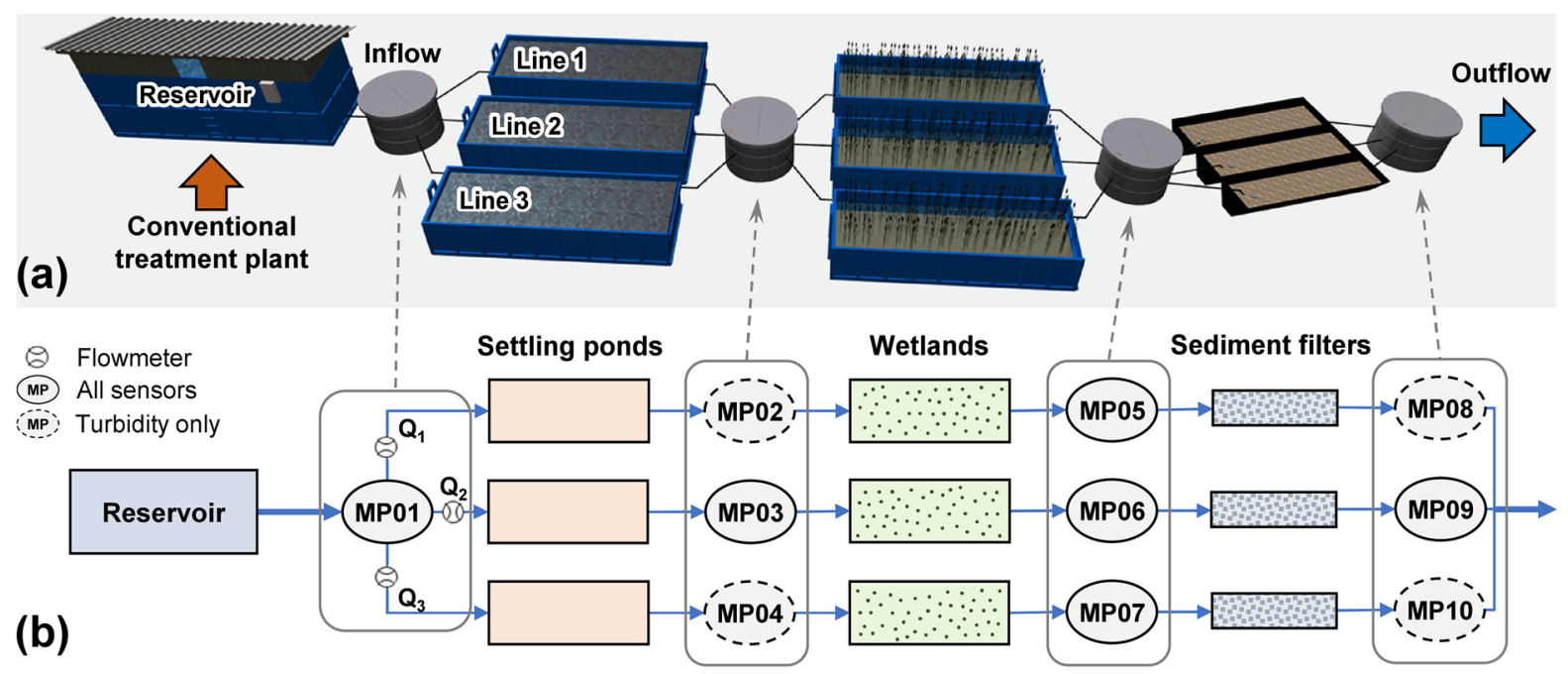

Fig. 2 Pilot plant setup: (a) 3D-illustration (without terrain) and (b) schematic 
The overall flow rate in the pilot plant was governed by the filling level of the gravitationally drained reservoir, which was in turn discontinuously filled during operation of the conventional plant on site. At normal operation, the reservoir allowed operation of the pilot system at $\approx 800 \mathrm{~L} / \mathrm{h}$ (lower to upper quartiles 746-851 L/h). During weekends, progressing emptying of the reservoir resulted in considerable flow fluctuations in at least one of the three system lines with temporary drops in the overall flow rate as low as 400 $\mathrm{L} / \mathrm{h}$.

According to the hydraulic monitoring of the drainage pond, the overall water yield after sealing and rehabilitation of the Westfield landfill is estimated in the order of 175,000-200,000 m³. Accordingly, the Westfield pilot plant continuously treated up to $4 \%$ of the overall (seepage) water yield, underlining the scale of the Westfield legacy.

\subsection{Hydrochemical Monitoring}

A multiparameter monitoring system (WTW IQ Sensor Net) was installed at the Westfield pilot plant for continuous logging of basic hydrochemical parameters at a 30-min interval. All monitoring points were equipped with turbidity sensors. Additionally, the central line and wetland outflows (MP01, MP03, MP05-MP07, MP09) were equipped with temperature, electrical conductivity, $\mathrm{pH}$ and dissolved oxygen sensors (Fig. 2b). The fixed sensors were doublechecked weekly and further complemented by redox potential measurements with hand-held metres (WTW Multi 3530).

Water samples for multiparameter analysis were collected weekly at all monitoring points. One sample was immediately filtered $(0.45 \mu \mathrm{m})$ and stabilised with 150 $\mu \mathrm{L}$ of $3.6 \% \mathrm{HCl}$ for cation analysis via ICP-OES (Al, $\mathrm{Ba}, \mathrm{Ca}, \mathrm{Cr}, \mathrm{Cu}, \mathrm{K}, \mathrm{Mg}, \mathrm{Na}, \mathrm{Ni}, \mathrm{Pb}, \mathrm{V}, \mathrm{Zn}$ ) and trace analysis via graphite tube AAS for Mn (weekly) and As (monthly). A second sample was collected and immediately frozen for (an)ion analysis via ion chromatography $\left(\mathrm{Br}, \mathrm{Cl}, \mathrm{F}, \mathrm{NO}_{2}, \mathrm{NO}_{3}, \mathrm{PO}_{4}, \mathrm{SO}_{4}\right)$ and photometry $\left(\mathrm{NH}_{4}, \mathrm{PO}_{4}, \mathrm{SO}_{4}\right)$. A third sample was collected for total organic and inorganic carbon (TOC, TIC) measurements. Samples for analysis of Fe as the primary contaminant were collected twice weekly at all monitoring points and subjected to spectrophotometric analysis of dissolved ferrous and ferric as well as particulate and total $\mathrm{Fe}$ as described by Matthies et al. (2012) and Opitz et al. (2020). Acidity was calculated from analytical results and corrected for $\mathrm{CO}_{2}$ using PHREEQC broadly following Kirby and Cravotta (2005). After the initial test period, the analytical scope was considerably reduced as several parameters (especially metals) were consistently close to or below detection limit as already established by the long-term seepage water monitoring. Furthermore, TSS monitoring was substituted by daily averaged, in situ turbidity monitoring as an indirect, yet higher resolution measurand of suspended solids (Pfannkuche \& Schmidt, 2003) because TSS in sediment filter outflows was invariably below detection limit. All chemicals used for stabilisation, analytics and standards were analytical grade.

For comparison of the consecutive treatment stages of the trifurcated pilot system, substance concentrations along the three system lines $\left(C_{1}\right.$ to $\left.C_{3}\right)$ are weight proportional to the respective flow rate $\left(Q_{1}\right.$ to $\left.Q_{3}\right)$ to calculate a median concentration $\left(C_{m}\right)$ :

$C_{m}=\frac{\sum_{i=1}^{3}\left(Q_{i} \times C_{i}\right)}{\sum_{i=1}^{3} Q_{i}}$

Rough mass balance estimates are based on the respective sampling intervals noted above. Mass loading $\left(m_{l}\right)$ is calculated from concentrations and flow rates of the three system lines multiplied with the respective time interval around the sampling event $\left(t_{s}\right)$ over the entire study period $(t)$.

$m_{l}=\sum_{0}^{t} t_{s} \times \sum_{i=1}^{3}\left(C_{i} \times Q_{i}\right)$

The average (daily) loading $(L)$ is calculated by dividing the mass loading $\left(m_{l}\right)$ by the length of the respective study period $\left(t_{i}\right)$ :

$L=\frac{m_{l}}{t_{i}}$

Hydrochemical monitoring data from the conventional treatment plant operated at the Westfield site was provided by courtesy of the plant operator. The database comprised monthly chemical analyses of raw and treated water (inflow/outflow) since the last major restoration of the conventional treatment plant in 2010 . 


\section{Results and Discussion}

\subsection{Hydrochemistry}

In a first step, the extensive dataset collected from the Westfield pilot plant over the 452-day study period was used to categorise basic parameters and chemical species by their overall change from inflow to outflow. Four distinct categories were identified by evaluating flow-weighed medians irrespective of minor spatiotemporal variations: Firstly, easily soluble compounds $\left(\mathrm{Br}, \mathrm{Ca}, \mathrm{Cl}, \mathrm{F}, \mathrm{K}, \mathrm{Mg}, \mathrm{Na}, \mathrm{SO}_{4}\right)$ and electrical conductivity displayed a conservative behaviour with overall changes $<5 \%$. Besides quality control, this also shows that external effects such as dilution by rainwater or evapoconcentration are negligible for the aggregated datasets. Secondly, several compounds (Fe, As, Mn, $\mathrm{NH}_{4}$, TSS/turbidity) displayed a substantial decrease in concentration $\geq 25 \%$, whereas thirdly, a major increase was only observed for $\mathrm{NO}_{3}$ and redox potential. Fourthly, minor removal or increase in the order of 5-25\% was observed for TOC and TIC as well as acidity, oxygen saturation and $\mathrm{pH}$. As noted above, most metals ( $\mathrm{Al}, \mathrm{Cr}, \mathrm{Cu}, \mathrm{Ni}, \mathrm{Pb}, \mathrm{V}$, $\mathrm{Zn})$ are negligible in the seepage water.
In a second step, the development of relevant parameters and especially contaminants was further analysed. Beyond the mere change in overall concentration, the comprehensive individual monitoring of consecutive treatment stages allowed identification of specific patterns and trends as well as clear assignment of overall (i.e. for the entire system) and discrete (i.e. for individual stages) treatment efficiency for relevant contaminants (Fe, As, $\mathrm{Mn}, \mathrm{NH}_{4}, \mathrm{NO}_{3}$, turbidity).

First and foremost, similar removal patterns for $\mathrm{Fe}$, turbidity and $\mathrm{As}$ on the one hand and $\mathrm{Mn}, \mathrm{NH}_{4}$ and $\mathrm{NO}_{3}$ (inverse) on the other hand are clearly discernible in Fig. 3 as indicated by concave and convex arrows, respectively, and as further detailed below. The development of basic hydrochemical parameters from the first and fourth category is displayed in Fig. S1 with selected trends particularly in wetlands briefly outlined in the following, predominantly based on lower and upper quartiles to take account of natural and stochastic fluctuations in the open system. For instance, dissolved oxygen was close to saturation in the open system with a notable drop from settling ponds (94-101\%) to wetlands (67-82\%) and little further change in sediment filters. Correspondingly, the redox potential slightly decreased from 102-174 in
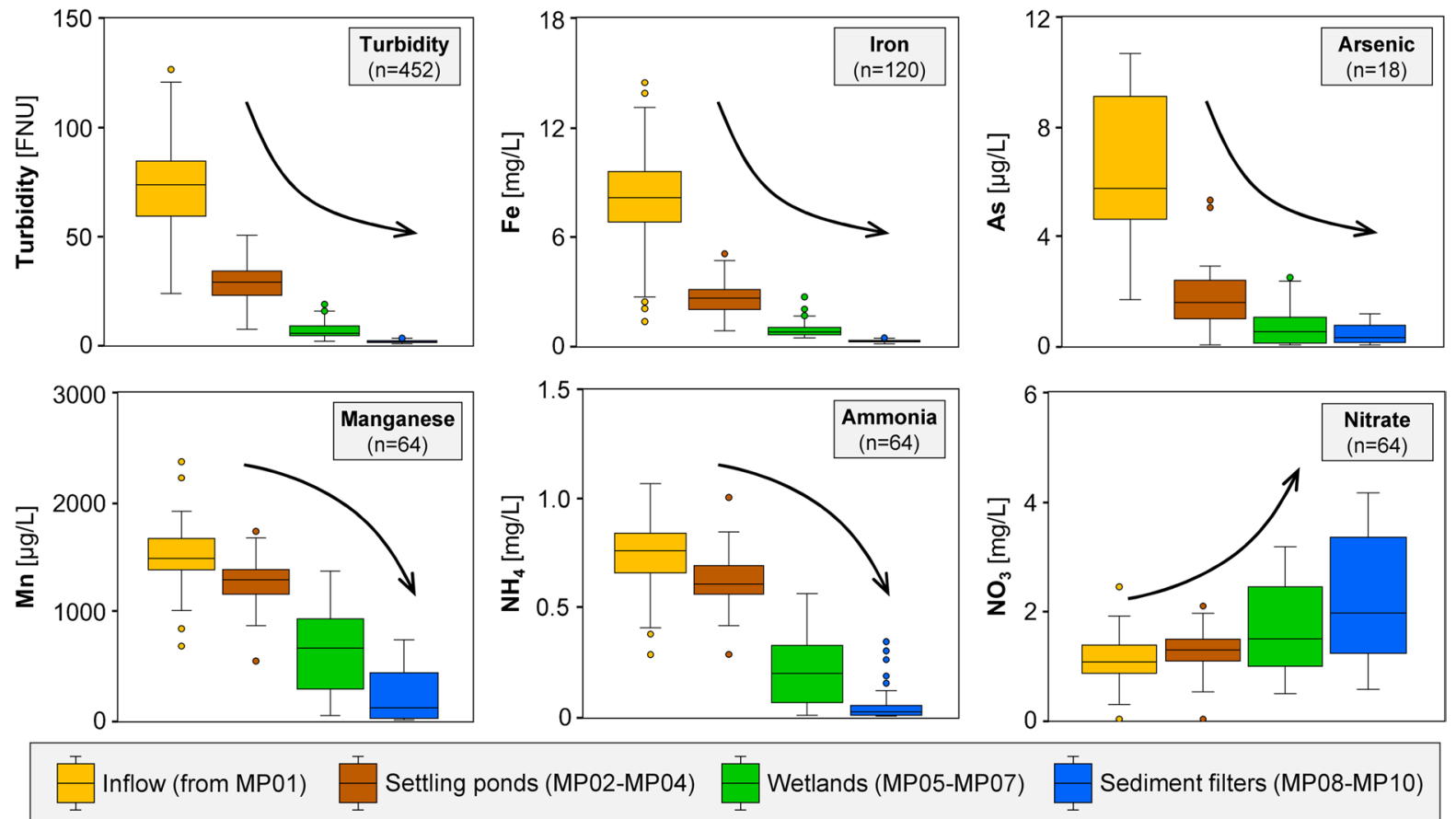

Fig. 3 Development of relevant contaminants in the Westfield pilot plant through the study period as median concentrations $\left(C_{m}\right)$ with number of samples per boxplot in brackets and arrows indicating removal progression 
settling ponds to $88-140 \mathrm{mV}$ in wetlands-yet consistently increased to $179-222 \mathrm{mV}$ in sediment filters. TOC increased in settling ponds and especially wetlands by $10-15 \%$, each. This increase, albeit at a relatively low TOC level of $0.6-1.1 \mathrm{mg} / \mathrm{L}$, is in accordance with visual observation of organic residues and biofilms attached to pipework and sensors at wetland outflows (MP05-MP07). However, TOC decreased again in sediment filters, resulting in a moderate overall TOC increase (median 15\%) throughout the pilot plant. Overall, the monitoring indicated the onset of microbial and/or oxidation processes in wetlands that continued in sediment filters, with the latter effectively removing redox-sensitive and wetland-derived organic compounds, presumably through filtration, attachment and mineralisation in the filter matrix (Garciá et al., 2003).

Additionally, several temporal environmental and ecological patterns were identified through the highresolution in situ monitoring of basic hydrochemical parameters. For instance, spring blooms of floating and epiphytic algae in wetlands caused a diurnal cycle in oxygen concentration with a sharp increase during the day (up to $14 \mathrm{mg} / \mathrm{L}$ ) that was reversed after sunset (as low as $4 \mathrm{mg} / \mathrm{L}$ ). Concomitantly, the photorespiratory cycle of algae and macrophytes caused a diurnal $\mathrm{pH}$ amplitude in wetlands (up to one $\mathrm{pH}$ unit). Both amplitudes were, again, mitigated in sediment filters and rapidly declined after emergence of dense, tallgrowing reed stands and concomitant senescence of algae, dwindling away over the course of the summer. Beyond that, seepage water $\mathrm{pH}$ was relatively stable throughout the pilot system at 7.4-7.6 with an interim peak at 7.8-8.0 in settling ponds. This $\mathrm{pH}$ increase is attributable to $\mathrm{CO}_{2}$ degassing as confirmed by a slight decrease $(\approx 7 \%)$ in TIC and stable $\mathrm{CO}_{2}$-corrected acidity (Fig. S1).

\subsection{Contaminant Removal}

\subsubsection{Iron, Arsenic and TSS/Turbidity}

Generally, Fe, As and TSS were predominantly retained in settling ponds (63-77\%) with little further accumulation in wetlands (20-31\%) and sediment filters (4-6\%). However, the discrete treatment efficiency of the three consecutive treatment stages for $\mathrm{Fe}$, As and TSS was very similar or even increased in wetlands and/or sediment filters even though the latter stages received substantially lower loadings. By way of example, discrete median removal in settling ponds, wetlands and sediment filters was 69,73 and $72 \%$ for $\mathrm{Fe}$ and 62,82 and $78 \%$ for turbidity, respectively (Table 2). Overall, Fe levels decreased from an average of $8.4( \pm 2.4)$ in the inflow to $0.21( \pm 0.07)$ $\mathrm{mg} / \mathrm{L}$ in sediment filter outflows during the study

Table 2 Transport and removal of relevant contaminants in the Westfield pilot plant through the study period: Concentration development ${ }^{1}$ and contaminant removal ${ }^{2}$

\begin{tabular}{llllll}
\hline Parameter & & Inflow (MP01) & $\begin{array}{l}\text { Settling pond outflows } \\
\text { (MP02-MP04) }\end{array}$ & $\begin{array}{l}\text { Wetland outflows } \\
\text { (MP05-MP07) }\end{array}$ & $\begin{array}{l}\text { Sediment filter } \\
\text { outflows (MP08- } \\
\text { MP10) }\end{array}$ \\
\hline Turbidity & Conc. [FNU] & $73(55-85)$ & $27(21-33)$ & $4.9(3.8-8.1)$ & $1.1(0.72-1.5)$ \\
& Removal & $0 \%(0 \%)$ & $62 \%(62 \%)$ & $93 \%(82 \%)$ & $99 \%(78 \%)$ \\
$\mathrm{Fe}$ & Conc. [mg/L] & $8.1(6.9-9.6)$ & $2.5(1.8-3.0)$ & $0.69(0.55-0.93)$ & $0.19(0.17-0.25)$ \\
& Removal & $0 \%(0 \%)$ & $69 \%(69 \%)$ & $92 \%(73 \%)$ & $98 \%(72 \%)$ \\
$\mathrm{As}$ & Conc. $[\mu \mathrm{g} / \mathrm{L}]$ & $5.8(4.7-8.9)$ & $1.6(0.99-2.3)$ & $0.48(0.10-0.91)$ & $0.27(0.10-0.64)$ \\
& Removal & $0 \%(0 \%)$ & $73 \%(73 \%)$ & $92 \%(69 \%)$ & $95 \%(44 \%)$ \\
$\mathrm{Mn}$ & Conc. $[\mathrm{mg} / \mathrm{L}]$ & $1.5(1.4-1.7)$ & $1.3(1.2-1.4)$ & $0.66(0.29-0.92)$ & $0.11(0.02-0.43)$ \\
& Removal & $0 \%(0 \%)$ & $13 \%(13 \%)$ & $56 \%(49 \%)$ & $92 \%(83 \%)$ \\
$\mathrm{NH}_{4}$ & Conc. $[\mathrm{mg} / \mathrm{L}]$ & $0.76(0.66-0.84)$ & $0.61(0.57-0.69)$ & $0.20(0.07-0.32)$ & $0.02(0.01-0.05)$ \\
& Removal & $0 \%(0 \%)$ & $20 \%(20 \%)$ & $74 \%(68 \%)$ & $97 \%(90 \%)$ \\
$\mathrm{NO}_{3}$ & Conc. $[\mathrm{mg} / \mathrm{L}]$ & $1.1(0.84-1.4)$ & $1.3(1.1-1.5)$ & $1.5(1.0-2.4)$ & $2.0(1.2-3.4)$ \\
& Removal & $0 \%(0 \%)$ & $-21 \%(-21 \%)$ & $-40 \%(-16 \%)$ & $-85 \%(-32 \%)$ \\
\hline
\end{tabular}

\footnotetext{
${ }^{1}$ Median concentrations with the spread characterised by lower and upper quartiles in brackets.

${ }^{2}$ Overall cumulative removal through the system and (as italics in brackets) discrete removal for individual components.
} 

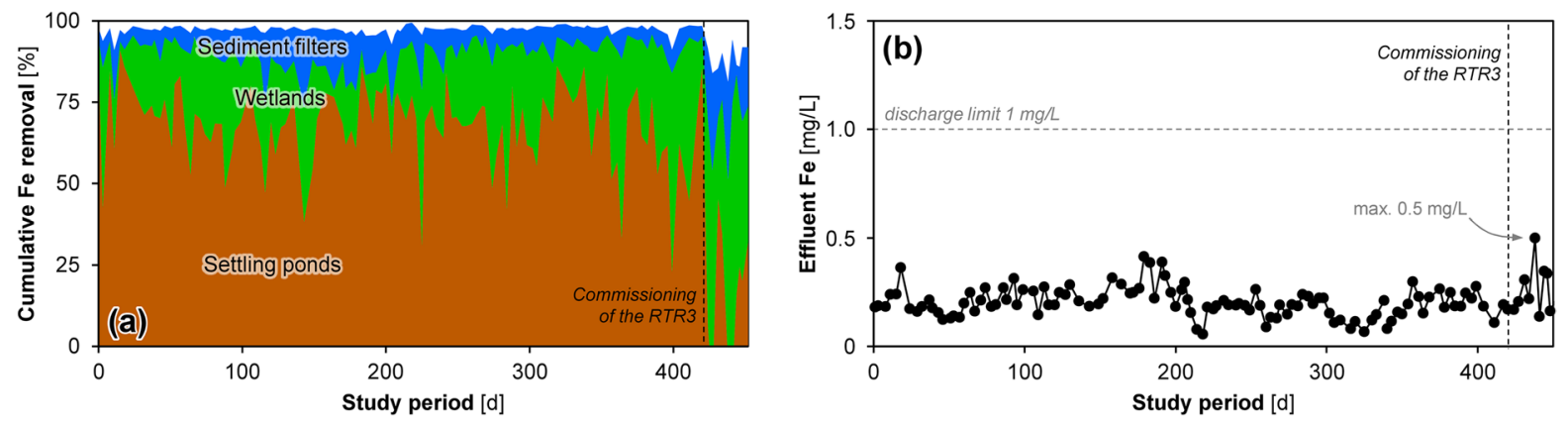

Fig. 4 Iron monitoring through the study period with (a) cumulative removal and (b) effluent concentration

period. The maximum effluent $\mathrm{Fe}$ concentration was $0.50 \mathrm{mg} / \mathrm{L}$ for flow-weighted $(n=120)$ or $0.67 \mathrm{mg} / \mathrm{L}$ for individual $(n=360)$ measurements, respectively, and thus well below the site-specific discharge limit of $1 \mathrm{mg} / \mathrm{L}$ (Fig. 4b). In mining environments, it is commonly observed that TSS and turbidity are predominantly attributable to dispersed hydrous ferric oxides that also cause the characteristic ochreous discoloration of ferruginous, circumneutral mine waters. This was previously established for the Westfield pilot plant where turbidity and (particulate) Fe are closely correlated (Opitz et al., 2020). Accordingly, Fe and turbidity show similar removal patterns along the consecutive treatment stages, with turbidity decreasing from an average of $69( \pm 22)$ FNU in the inflow to $1.2( \pm 0.6)$ FNU in the outflow (Fig. S2).

The trace levels of As detected in the inflow were consistently decreased close to or below detection limit in sediment filter outflows (Table 2). There is good reason to assume that As was largely associated (and thus removed) with the hydrous ferric oxide phases as commonly reported for As in ferruginous mining environments (Park et al., 2016). This is substantiated by the fact that the median Fe:As molar ratios were almost even at approx. 2000: 1 throughout inflow, settling ponds and wetlands, eventually decreasing to about 1000:1 in sediment filters where $\mathrm{Fe}$ and especially As were marginally low.

Altogether, the removal of particulate (ferric) solids and associated compounds such as As throughout the multistage system was predominantly governed by physical processes such as sedimentation and filtration. This is substantiated by the fact that no major seasonal or other spatiotemporal trends were discernible over the study period for Fe, turbidity or
As. Overall, the objective of progressing treatment broadly following Pareto's principle was achieved for $\mathrm{Fe}$ as the primary contaminant, confirming the application potential of passive treatment at the Westfield site and providing proof of operational reliability in due consideration of the strict regulatory requirements (Fig. 4b).

\subsubsection{Manganese, Ammonia and Nitrate}

As the seepage water $\mathrm{pH}$ showed a peak in settling ponds at up to $\mathrm{pH} 8$, it may have been expected that $\mathrm{Mn}$ (II) oxidation rates were highest in settling ponds. However, only minor Mn removal in the order of $13 \%$ was observed in settling ponds (Table 2). In contrast, Fig. 5a shows that Mn removal was stimulated in wetlands and further soared in sediment filters with discrete median removal of 49 and $83 \%$, respectively, effectively reducing $\mathrm{Mn}$ levels from an average of $1.5( \pm 0.3) \mathrm{mg} / \mathrm{L}$ in the inflow to $<0.5 \mathrm{mg} / \mathrm{L}$ in the outflow. There is good reason to assume that $\mathrm{Mn}$ (II) oxidation and subsequent precipitation in the Westfield pilot plant was catalysed by respective microbial communities closely linked with reactive surfaces in wetlands and especially in the sediment filter matrix (Luan et al., 2012; Neculita \& Rosa, 2019). This is substantiated by black Mn(III/IV)-(oxyhydr)oxide coatings of plant litter in wetlands, the pipework succeeding wetland outflows and especially the granite gravel in sediment filters (Fig. S3). Also, the lowest Mn removal in the Westfield pilot system was observed in winter (January 2018 and January 2019). Nevertheless, even at low temperatures, Mn removal exceeded $50 \%$ from inflow to outflow, and no remobilisation or net export of $\mathrm{Mn}$ as reported by Goulet and Pick (2001) was observed. 
Analogously, only minor $\mathrm{NH}_{4}$ removal in the order of $20 \%$ was observed in settling ponds (Fig. 5b). Nitrification showed a similar trend as $\mathrm{Mn}(\mathrm{II})$ oxidation, soaring in wetlands and further increasing in sediment filters with median discrete $\mathrm{NH}_{4}$ removal rates of 68 and $90 \%$, respectively (Table 2). A simple correlation analysis highlights that removal of both $\mathrm{Mn}$ and $\mathrm{NH}_{4}$ is correlated with temperature in settling ponds as would be expected for predominantly physicochemical oxidation. Only moderate correlations are found in wetlands where a potential temperature effect is likely masked by phytologic, microbial and
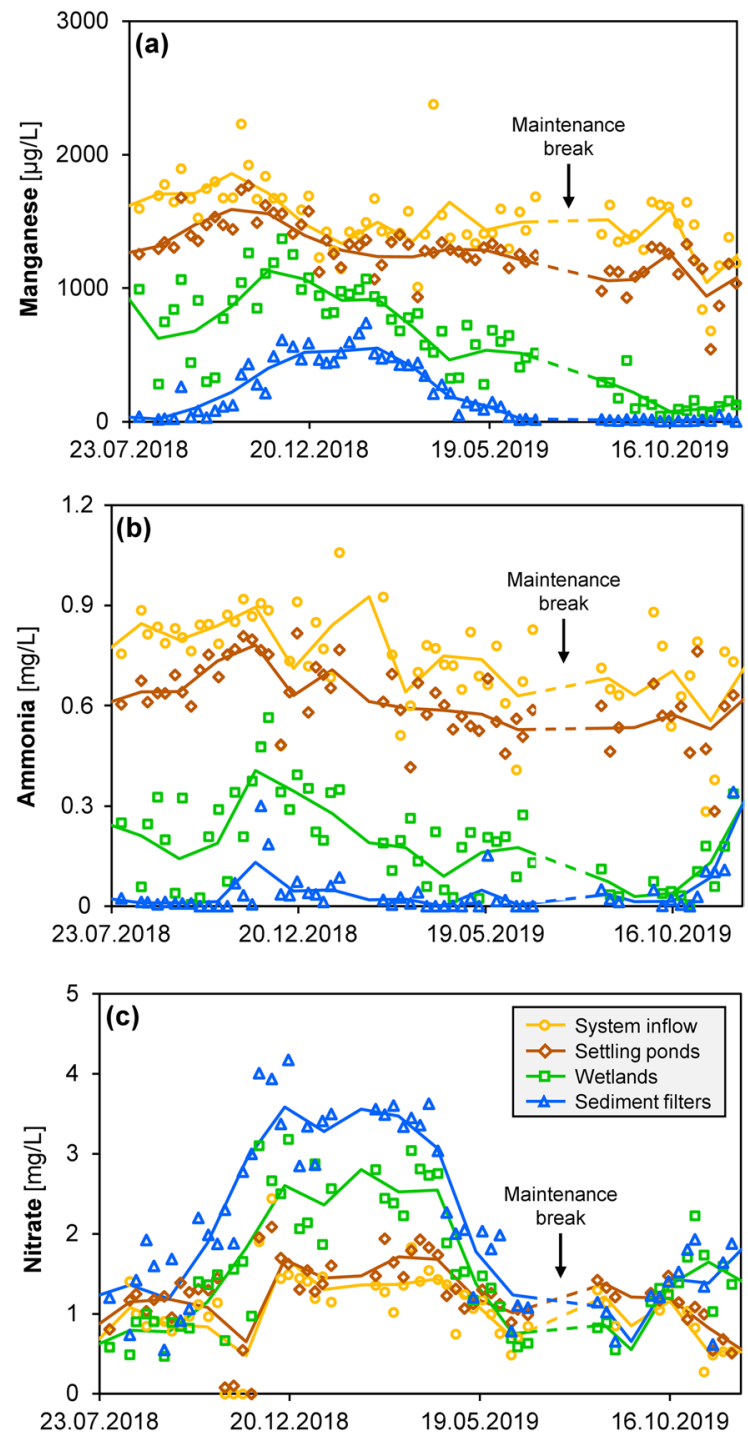

Fig. 5 Monitoring of (a) $\mathrm{Mn}$, (b) $\mathrm{NH}_{4}$ and (c) $\mathrm{NO}_{3}$ in the Westfield pilot plant through the study period with solid lines indicating monthly averages (legend applies to all diagrams) surface-catalytic effects. Overall, wetlands accounted for $56 \%$ of $\mathrm{NH}_{4}$ removal, thus highlighting the importance of the densely vegetated, near-natural environment for nitrification (Cui et al., 2020). Nitrification caused a concomitant increase in $\mathrm{NO}_{3}$ (median $85 \%$ ), nearly doubling median $\mathrm{NO}_{3}$ levels from an average of $1.1( \pm 0.4)$ in the inflow to $2.2( \pm 1.0) \mathrm{mg} / \mathrm{L}$ in the outflow. However, it is interesting to note that $\mathrm{NH}_{4}$ basically decreased year-round, whereas $\mathrm{NO}_{3}$ increase was apparently higher in autumn and winter (approx. September to April) as illustrated in Fig. 5b,c. There is reason to assume that $\mathrm{NO}_{3}$ generation did not decrease in spring and summer, but rather that a nitrogen fraction was fixed in plants, litter and sediment as a result of primary production (algae, macrophytes) and/or lost to the atmosphere as $\mathrm{N}_{2}$ as a result of denitrification in sediment and substrate (Griffiths et al., 2021). The nitrogen mass balance and deficit are further explored below.

\subsection{Mass Balances}

For Fe, the average time interval of the mass balance was 3.7 days. Mass loading is estimated at $69 \mathrm{~kg}$ over the study period with an average loading of $153 \mathrm{~g} / \mathrm{d}$. About $48 \mathrm{~kg}$ were retained in settling ponds, $15 \mathrm{~kg}$ in wetlands and $5.3 \mathrm{~kg}$ in sediment filter, and only $1.8 \mathrm{~kg}$ $(<3 \%)$ were discharged which is in accordance with previous estimates (Opitz et al., 2020). Thus, most (69\%) Fe was retained in settling ponds as hydrous ochre, thereby protecting subsequent treatment stages as well as allowing for efficient desludging and potential valorisation of the relatively pure ochre (Hedin, 2003).

For As, the average time interval of the mass balance was 25 days and should thus be treated with caution. The mass loading is estimated at $55 \mathrm{~g}$ over the study period with an average loading of $121 \mathrm{mg} / \mathrm{d}$. About $38 \mathrm{~g}$ were retained in settling ponds, $9.9 \mathrm{~g}$ in wetlands and $3.2 \mathrm{~g}$ in sediment filters, and only $3.2 \mathrm{~g}(<6 \%)$ were discharged. For Mn, the average time interval of the mass balance was 7.1 days. The mass loading is estimated at $13 \mathrm{~kg}$ over the study period with an average loading of $29 \mathrm{~g} / \mathrm{d}$. Only about $2.1 \mathrm{~kg}$ were retained in settling ponds, whereas 5.4 and $3.6 \mathrm{~kg}$ were retained in wetlands and sediment filters, respectively. About $1.8 \mathrm{~kg}(<14 \%)$ were discharged, most of it in winter. The divergence between the median removal efficiency in Table 3 and the 
Table 3 Mass balance of the Westfield pilot plant for relevant contaminants through the study period: Mass loading $\left(m_{l}\right)$ with average daily loading $(L)$ in brackets

\begin{tabular}{llllll}
\hline Loading & $\mathrm{Fe}$ & $\mathrm{As}$ & $\mathrm{Mn}$ & $\mathrm{NH}_{4}-\mathrm{N}$ & $\mathrm{NO}_{3}-\mathrm{N}$ \\
\hline Settling pond loading (MP01) & $69 \mathrm{~kg}(153 \mathrm{~g} / \mathrm{d})$ & $55 \mathrm{~g}(121 \mathrm{mg} / \mathrm{d})$ & $13 \mathrm{~kg}(29 \mathrm{~g} / \mathrm{d})$ & $349 \mathrm{~mol}(0.77 \mathrm{~mol} / \mathrm{d})$ & $145 \mathrm{~mol}(0.32 \mathrm{~mol} / \mathrm{d})$ \\
Wetland loading (MP02-MP04) & $22 \mathrm{~kg}(48 \mathrm{~g} / \mathrm{d})$ & $16 \mathrm{~g}(36 \mathrm{mg} / \mathrm{d})$ & $11 \mathrm{~kg}(24 \mathrm{~g} / \mathrm{d})$ & $294 \mathrm{~mol}(0.65 \mathrm{~mol} / \mathrm{d})$ & $171 \mathrm{~mol}(0.38 \mathrm{~mol} / \mathrm{d})$ \\
$\begin{array}{l}\text { Sediment filter loading (MP05- } \\
\text { MP07) }\end{array}$ & $7.0 \mathrm{~kg}(16 \mathrm{~g} / \mathrm{d})$ & $6.4 \mathrm{~g}(14 \mathrm{mg} / \mathrm{d})$ & $5.4 \mathrm{~kg}(12 \mathrm{~g} / \mathrm{d})$ & $96 \mathrm{~mol}(0.21 \mathrm{~mol} / \mathrm{d})$ & $224 \mathrm{~mol}(0.50 \mathrm{~mol} / \mathrm{d})$ \\
\begin{tabular}{l} 
Discharge (MP08-MP10) \\
\hline
\end{tabular} & $1.8 \mathrm{~kg}(3.9 \mathrm{~g} / \mathrm{d})$ & $3.2 \mathrm{~kg}(7.1 \mathrm{mg} / \mathrm{d})$ & $1.8 \mathrm{~kg}(4.0 \mathrm{~g} / \mathrm{d})$ & $21 \mathrm{~mol}(0.05 \mathrm{~mol} / \mathrm{d})$ & $296 \mathrm{~mol}(0.66 \mathrm{~mol} / \mathrm{d})$ \\
\hline
\end{tabular}

mass balance estimates is attributable to the seasonal variation of $\mathrm{Mn}(\mathrm{II})$ oxidation rates in sediment filters (Table S2) with overall Mn removal ranging from $>90 \%$ in summer to $60-70 \%$ in winter.

A simple nitrogen mass balance was established based on $\mathrm{NH}_{4}-\mathrm{N}$ and $\mathrm{NO}_{3}-\mathrm{N}$ as notable nitrogen species in the seepage water with $\mathrm{NO}_{2}$ largely below detection limit (Fig. 6). The overall nitrogen loading is estimated at 495 mol over the study period at an average loading of $1.1 \mathrm{~mol} / \mathrm{d}$, with an estimated overall $\mathrm{NH}_{4}-\mathrm{N}$ removal of $\approx 328 \mathrm{~mol}$ and $\mathrm{NO}_{3}-\mathrm{N}$ generation of $\approx 151$ mol over the study period. Most notably, the wetlands showed a substantial nitrogen deficit in the order of 144 mol that correlates with the seasonal variation in $\mathrm{NO}_{3}$ outlined above. Investigation of monospecific reed stands by Schieferstein (1999) showed that nitrogen assimilation by common reed is highest in early spring, whereas nitrogen re-cycling from plant litter and detritus may be expected as of late summer. This is in accordance with year-round nitrate mobility in wetlands of the Westfield pilot system (Fig. 5c), which leads us to believe that a sizeable nitrogen fraction is assimilated by plants during spring and summer, yet partly re-mobilised upon decomposition and mineralisation of plant litter during autumn and winter. This is substantiated by the correlation analysis, showing that the seasonal effect induces a positive correlation in wetlands as opposed to negative correlations in settling ponds and sediment filters (Table S2). Overall, the Westfield pilot system showed a net-negative nitrogen budget of $\approx 178 \mathrm{~mol}$ $(\approx 36 \%)$ over the study period, with allocation of the deficit to (temporary) fixation (plants, sediment, litter) and $\mathrm{N}_{2}$ degassing unknown. Median $\mathrm{NH}_{4}-\mathrm{N}$ removal rates in wetlands may be broadly estimated at up to $8.8 \mathrm{mmol} / \mathrm{m}^{2} / \mathrm{d}$, which is in accordance with literature reports in the order of $1-20 \mathrm{mmol} / \mathrm{m}^{2} / \mathrm{d}$ (Dzakpasu et al., 2014; Mitsch \& Gosselink, 2000).

\subsection{Comparison of Conventional Plant and Passive Pilot System}

The aggregated median concentration development of relevant parameters in the Westfield passive pilot system and the full-scale conventional treatment plant operated on site are illustrated in Fig. 7. It should be noted that juxtaposition of relative treatment efficiencies for two water treatment plants is only valid if the underlying absolute inflow levels are broadly similar. Although the pilot system was directly fed from the conventional plant, a comparability test was made for the aggregated long-term datasets as the respective monitoring periods are non-identical. The comparison in Table S1 shows that inflow concentrations consistently overlap

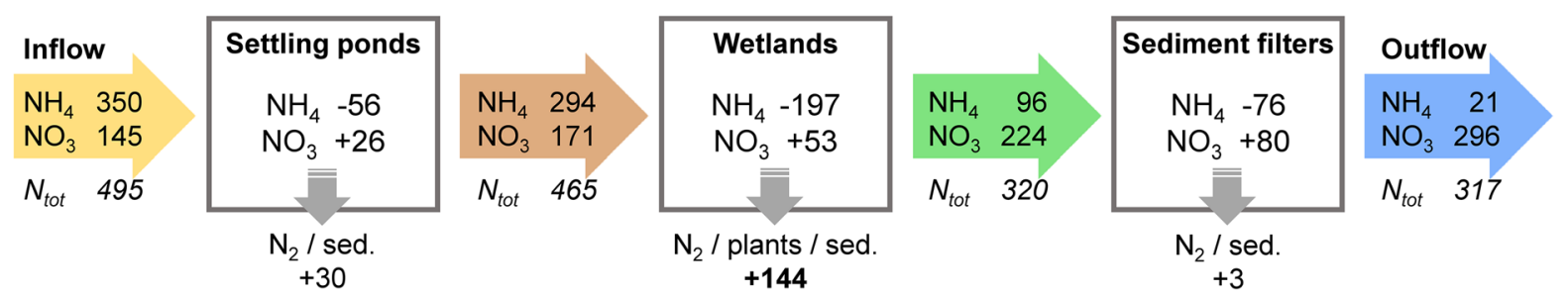

Fig. 6 Overall nitrogen mass balance for the Westfield pilot plant over the study period in [mol] 
with relative differences of long-term medians well below $20 \%$. The sole exception is $\mathrm{Cl}$ due to the long-time falling trend noted in Table 1. Hence, seepage water chemistry remained relatively stable over the years, and we consider the two aggregated databases as broadly comparable as long as differences indicated by Table $\mathrm{S} 1$ are taken into account.

First and foremost, Fig. 7 shows that the two treatment plants are comparable in terms of $\mathrm{Fe}$ removal as the primary contaminant, both reliably meeting the regulatory requirements. The same holds true for TSS/turbidity and As. However, both $\mathrm{Mn}$ and $\mathrm{NH}_{4}$ mostly pass the conventional treatment plant with overall median removal in the order of $5-10 \%$, rarely exceeding $20 \%$. This goes to show that the biogeochemical processes stimulated in the near-natural wetland environment together with the high-surface sediment filters provide a technological benefit regarding overall water quality amelioration.

The addition of lime slurry and ferric chloride solution in the conventional treatment plant as alkalising and flocculating agents, respectively, measurably increase the intrinsically conservative ions $\mathrm{Ca}$ and $\mathrm{Cl}$ (data not shown). The median percentage increase is relatively minor $(\mathrm{Ca} \approx 3 \% ; \mathrm{Cl} \approx 9 \%$ ), yet because of the high initial loadings noted in Table 1, the additional yearly discharge of $\mathrm{Ca}$ and $\mathrm{Cl}$ from the conventional treatment plant to the receiving surface water is estimated at 2.6-3.0 and 3.0-3.4 t/a, respectively. Although the conventional treatment plant at the Westfield site is relatively old and might thus fall short of the expected efficiency of modern physicochemical treatment plants, the underlying resource consumption of conventional mine water treatment is broadly transferrable and an environmental concern in the long run. In this context, passive treatment provides a more sustainable alternative for longterm water treatment, particularly at abandoned mining legacies.

\section{Evaluation of the Multistage Setup}

It is generally well-established that adequately designed and sized passive mine water treatment systems facilitate effective removal of $\mathrm{Fe}$ as the primary, ubiquitous contaminant in ferruginous, circumneutral mine waters and reliably meet regulatory discharge standards (e.g. Hedin, 2020; Sapsford \& Watson, 2011; Younger, 2000b). The multistage approach tested for the Westfield pilot system further advanced Fe removal efficiency, consistently achieving effluent concentrations well below the strict site-specific limit of $1 \mathrm{mg} / \mathrm{L}$ despite the heterogeneity in hydraulic loading and year-round environmental conditions as well as the predisposition of pilot-scale systems to performance fluctuations or operational failures. The

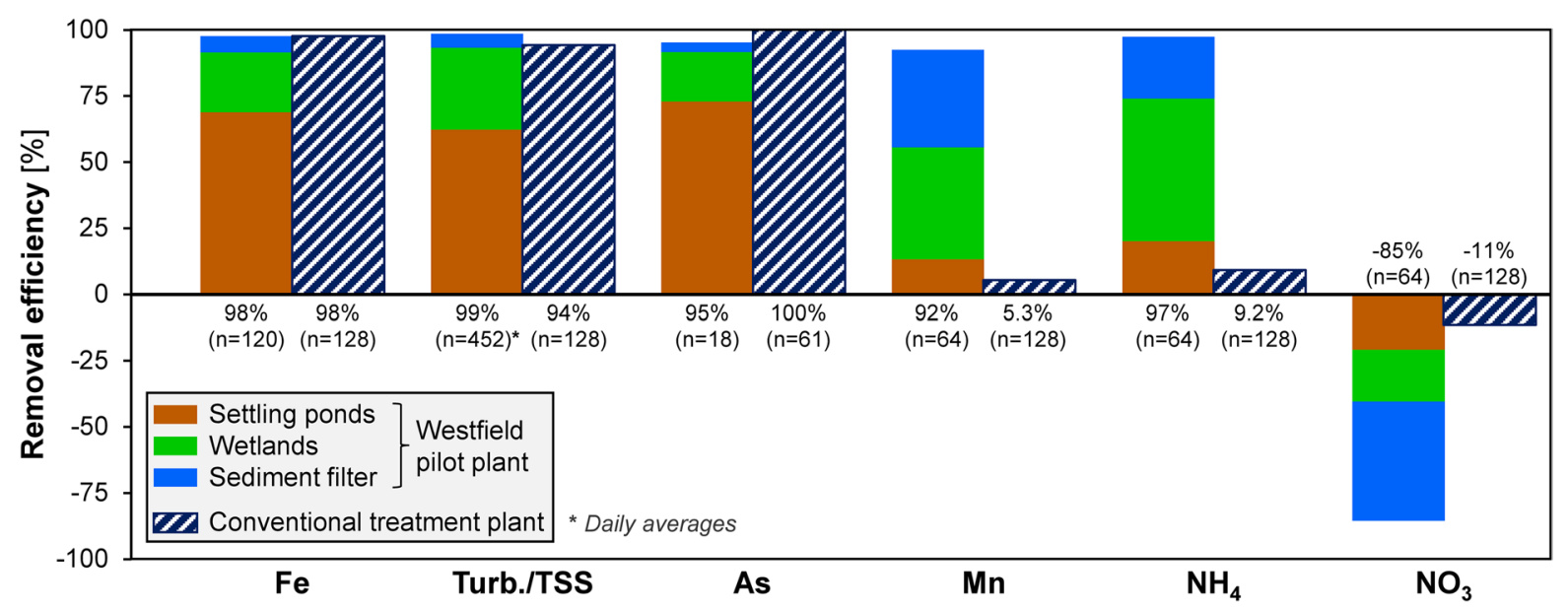

Fig. 7 Removal efficiency of relevant contaminants based on median inflow-outflow concentrations for the Westfield pilot plant (2018-2019) and the full-scale conventional treatment plant (2011-2021) with overall removal and number of samples indicated below columns 
removal of $\mathrm{Fe}$ as the primary contaminant as well as TSS/turbidity and As (broadly) followed the designated removal pattern according to Pareto's principle, with similar discrete removal efficiencies in the three consecutive stages of $60-80 \%$ (Table 2). By retaining the bulk Fe loading, the settling ponds effectively protected the more efficient, but also more delicate wetlands and sediment filters from overloading (i.e. clogging or colmation). Wetlands and sediment filters in turn ensured polishing at similar or even slightly higher discrete treatment efficiency despite substantially lower loading. Thus, the strategical combination of classical passive treatment stages is an effective means to facilitate reliable and effective treatment whilst potentially minimising maintenance and land requirements.

Generally, water quality improvement in settling ponds is predominantly limited to physicochemical processes such as gas exchange, autoxidation and sedimentation. Hence, the removal or decomposition of secondary contaminants such as $\mathrm{Mn}$ and $\mathrm{NH}_{4}$ was primarily stimulated in the vibrant and dynamic, near-natural environment of the densely vegetated wetlands and continued in sediment filters. Thus, the surface-flow wetlands are the centrepiece for not only polishing of residual $\mathrm{Fe}$, but also beneficial biogeochemical substance and redox cycles (Opitz et al., 2021). These observations are in accordance with previous studies on composite passive mine water treatment systems where wetlands were found to outperform settling ponds, not only for Fe but also Mn removal (e.g. Batty et al., 2008; Sapsford, 2013). Finally, the sediment filters were found to be a suitable means for overall polishing of particulate and redox-sensitive compounds ( $\mathrm{Fe}, \mathrm{As}, \mathrm{Mn}, \mathrm{NH}_{4}, \mathrm{TSS}$ ) whilst concomitantly mitigating spatiotemporal fluctuations that inevitably arise in near-natural open systems, including but not limited to turbidity, oxygen level, redox potential and TOC (Fig. 4 and Fig. S1).

Comprehensive, year-round datasets such as collected for the Westfield pilot plant provide a robust basis for assessment of treatment performance. Nevertheless, in-depth evaluation of the underlying temporal profiles is indispensable to identify spatiotemporal variations and interrelations in individual treatment stages. This was highlighted for the biogeochemical removal of $\mathrm{Mn}$ and $\mathrm{NH}_{4}$ which both (1) displayed an establishment phase with higher removal rates in the second and third compared to the first year of operation (data not shown) and (2) were subject to seasonal variation. The comprehensive monitoring together with visual observations indicate that development of plant cover, adapted microbial populations, biofilms, sediments and reactive surface coatings were the driving factors for $\mathrm{Mn}$ (II) oxidation and nitrification in surface-flow wetlands as previously suggested by Demin et al. (2002). The spatiotemporal fluctuations should, however, be kept in mind when interpreting treatment efficiency and mass balance estimates based on periodic samplings (Opitz et al., 2020). Altogether, it is to be expected that contaminant removal improves with maturation of the system until, eventually, sediment accumulation compromises the hydraulic efficiency. As biogeochemical trends and cycles in eco-technological systems are rather sluggish, necessary maintenance measures may be adequately predicted.

\section{Conclusions}

The study confirmed suitability and operational reliability of the multistage passive system for treatment of ferruginous, mining-influenced seepage water at the project site. The Westfield pilot system achieved excellent removal rates for $\mathrm{Fe}$ as the primary contaminant in the order of $98 \%$ with effluent concentrations averaging $0.21( \pm 0.07) \mathrm{mg} / \mathrm{L}$, thus reliably meeting the strict site-specific effluent limit of $1 \mathrm{mg} / \mathrm{L}$.

In-depth evaluation of the consecutive treatment stages showed that, whilst the bulk Fe load was retained in bare settling ponds, wetlands and sediment filters displayed similar discrete treatment efficiency and thus proved indispensable for polishing. The surface-flow wetlands were found to be the centrepiece of the multistage system, not only for Fe removal but also by stimulating and enhancing biogeochemical processes that contribute to the removal of secondary contaminants such as Mn and $\mathrm{NH}_{4}$. The sediment filters were found to be an eminently suitable means for overall polishing and to mitigate spatiotemporal variations of various hydrochemical parameters in the open system, including but not limited to TSS/turbidity, oxygen level, redox potential, $\mathrm{Fe}, \mathrm{As}, \mathrm{Mn}, \mathrm{NH}_{4}$ and TOC.

Fe removal efficiency of the multistage pilot system was comparable to the full-scale conventional treatment plant currently operated on site and even 
surpassed the latter in terms of $\mathrm{Mn} / \mathrm{NH}_{4}$ removal, thus demonstrating that passive treatment is a suitable and more sustainable alternative for long-term seepage water treatment at the project site.

Altogether, the pilot study showed that strategically combing increasingly efficient passive treatment stages broadly following the Pareto principle may allow for optimisation of treatment performance and operational reliability whilst providing an opportunity to minimise land consumption, maintenance requirements and overall costs. In addition, the multistage setup ensures that performance fluctuations in one stage are reliably mitigated in the consecutive treatment stage(s), thus minimising the overall risk of exceeding regulatory requirements.

Acknowledgements The study was conducted as part of a research project funded by the German Federal Environmental Foundation (project no. 33012/01-23). The authors thank Uniper Kraftwerke GmbH (Düsseldorf) for the support and for providing extensive datasets, as well as the laboratory staff of the University of Bayreuth, Department of Hydrology, for the meticulous assistance with sample analysis.

Funding Open Access funding enabled and organized by Projekt DEAL. The study was conducted as part of a research project funded by the German Federal Environmental Foundation (project no. 33012/01-23). The study was supported by Uniper Kraftwerke GmbH (Düsseldorf).

Data Availability The datasets used in this study are available from the corresponding author on reasonable request except for data that is subject to third party restrictions.

\section{Declarations}

Conflict of Interest The authors declare no competing interests.

Open Access This article is licensed under a Creative Commons Attribution 4.0 International License, which permits use, sharing, adaptation, distribution and reproduction in any medium or format, as long as you give appropriate credit to the original author(s) and the source, provide a link to the Creative Commons licence, and indicate if changes were made. The images or other third party material in this article are included in the article's Creative Commons licence, unless indicated otherwise in a credit line to the material. If material is not included in the article's Creative Commons licence and your intended use is not permitted by statutory regulation or exceeds the permitted use, you will need to obtain permission directly from the copyright holder. To view a copy of this licence, visit http://creativecommons.org/licenses/by/4.0/.

\section{References}

Batty, L., Hooley, D., \& Younger, P. (2008). Iron and manganese removal in wetland treatment systems: Rates, processes and implications for management. Science of the Total Environment, 394(1), 1-8. https://doi.org/10.1016/j. scitotenv.2008.01.002

Burrows, J., Cravotta, C., \& Peters, S. (2017). Enhanced Al and $\mathrm{Zn}$ removal from coal-mine drainage during rapid oxidation and precipitation of $\mathrm{Fe}$ oxides at near-neutral $\mathrm{pH}$. Applied Geochemistry, 78(1), 194-201. https://doi.org/10. 1016/j.apgeochem.2016.12.019

Chlot, S., Widerlund, A., Siergieiev, D., Ecke, F., Husson, E., \& Öhlander, B. (2011). Modelling nitrogen transformations in waters receiving mine effluents. Science of the Total Environment, 409, 4585-4595. https://doi.org/10. 1016/j.scitotenv.2011.07.024

Christenson, H., Pope, J., Trumm, D., Newman, N., Blanco, I., Kerr, G., Young, M., \& Uster, B. (2019). Manganese and trace element removal from New Zealand coal mine drainage using limestone leaching beds. New Zealand Journal of Geology and Geophysics, 62(2), 217-228. https://doi. org/10.1080/00288306.2018.1540995

Cravotta, C., \& Trahan, M. K. (1999). Limestone drains to increase $\mathrm{pH}$ and remove dissolved metals from acidic mine drainage. Applied Geochemistry, 14(5), 581-606. https://doi.org/10.1016/S0883-2927(98)00066-3

Cui, N., Thang, X., Zhou, L., Chen, G., \& Zou, G. (2020). Roles of vegetation in nutrient removal and structuring microbial communities in different types of agricultural drainage ditches for treating farmland runoff. Ecological Engineering, 155, 105941. https://doi.org/10.1016/j.ecole ng.2020.105941

Demin, O., Dudeney, A., \& Tarasova, I. (2002). Remediation of ammonia-rich minewater in constructed wetlands. Environmental Technology, 23(5), 497-514. https://doi. org/10.1080/09593332308618388

Dzakpasu, M., Scholz, M., McCarthy, V., \& Jordan, S. (2014). Nitrogen transformations and mass balance in an integrated constructed wetland treating domestic wastewater. Water Science \& Technology, 70(9), 1496-1502. https:// doi.org/10.2166/wst.2014.402

Eppink, F., Trumm, D., Weber, P., Olds, W., Pope, J., \& Cavanagh, J. (2020). Economic performance of active and passive AMD treatment systems under uncertainty: Case studies from the Brunner coal measures in New Zealand. Mine Water and the Environment, 39(4), 785-796. https:// doi.org/10.1007/s10230-020-00710-w

Etteib, S., Zolfaghari, M., Magdouli, S., Kaur Brar, K., \& Kaur Brar, S. (2021). Performance of constructed wetland for selenium, nutrient and heavy metals removal from mine effluents. Chemosphere, 281, 130921. https://doi.org/10. 1016/j.chemosphere.2021.130921

Evangelou, V., \& Zhang, Y. (1995). A review: Pyrite oxidation mechanisms and acid mine drainage prevention. Critical Reviews in Environmental Science and Technology, 25(2), 141-199. https://doi.org/10.1080/10643389509388477

García, J., Ojeda, E., Sales, E., Chico, F., Píriz, T., Aguirre, P., \& Mujeriego, R. (2003). Spatial variations of temperature, 
redox potential, and contaminants in horizontal flow reed beds. Ecological Engineering, 21(2), 129-142. https://doi. org/10.1016/j.ecoleng.2003.10.001

García, J., Chiva, J., Aguirre, P., Álvarez, E., Sierra, J., \& Mujeriego, R. (2004). Hydraulic behaviour of horizontal subsurface flow constructed wetlands with different aspect ratio and granular medium size. Ecological Engineering, 23(3), 177-187. https://doi.org/10.1016/j.ecoleng.2004. 09.002

Goulet, R., \& Pick, F. R. (2001). Changes in dissolved and total $\mathrm{Fe}$ and $\mathrm{Mn}$ in a young constructed wetland: Implications for retention performance. Ecological Engineering, 17(4), 373-384. https://doi.org/10.1016/S0925-8574(00)00161-0

Griffiths, L., Haupt, T., Zhang, L., \& Mitsch, W. (2021). Role of emergent and submerged vegetation and algal communities on nutrient retention and management in a subtropical urban stormwater treatment wetland. Wetlands Ecology and Management, 29(5), 245-264. https://doi.org/10. 1007/s11273-020-09781-6

Gu, B., Chimney, M., Newman, J., \& Nungesser, M. (2006). Limnological characteristics of a subtropical constructed wetland in south Florida (USA). Ecological Engineering, 27(4), 345-360. https://doi.org/10.1016/j.ecoleng.2006. 05.013

Hallberg, K., \& Johnson, D. (2005). Biological manganese removal from acid mine drainage in constructed wetlands and prototype bioreactors. Science of the Total Environment, 338(1-2), 115-124. https://doi.org/10.1016/j.scito tenv.2004.09.011

Hedin, R. (2003). Recovery of marketable iron oxide from mine drainage in the USA. Land Contamination and Reclamation, 11(2), 93-97. https://doi.org/10.2462/09670 513.802

Hedin, R. (2008). Iron removal by a passive system treating alkaline coal mine drainage. Mine Water and the Environment, 27(4), 200-209. https://doi.org/10.1007/ s10230-008-0041-9

Hedin, R. (2020). Long-term performance and costs for the Anna S mine passive treatment systems. Mine Water and the Environment, 39(2), 345-355. https://doi.org/10.1007/ s10230-020-00676-9

Hedin R, Nairn R, Kleinmann R, (1994) Passive treatment of coal mine drainage. Information Circular 9389, US Bureau of Mines.

Johnson, C. (2015). The fate of cyanide in leach wastes at gold mines: An environmental perspective. Applied Geochemistry, 57, 194-205. https://doi.org/10.1016/j.apgeochem. 2014.05.023

Kadlec R, Wallace S, (2009) Treatment wetlands (2nd ed.). CRC Press.

Kadlec R, Knight R, Vymazal J, Brix H, Cooper P, Haberl R, (2000). Constructed wetlands for pollution control: Processes, performance, design and operation. IWA Publishing.

Kirby, C., \& Cravotta, C. (2005). Net alkalinity and net acidity 1: Theoretical considerations. Applied Geochemistry, 20(10), 1920-1940. https://doi.org/10.1016/j.apgeochem. 2005.07.002

Kleinmann, R., Skousen, J., Wildemann, T., Hedin, R., Nairn, R., \& Gusek, J. (2021). The early development of passive treatment systems for mining-influenced water:
A North American perspective. Mine Water and the Environment, 40(4), 818-830. https://doi.org/10.1007/ s10230-021-00817-8

Luan, F., Santelli, C., Hansel, C., \& Burgos, W. (2012). Defining manganese(II) removal processes in passive coal mine drainage treatment systems through laboratory incubation experiments. Applied Geochemistry, 27(8), 1567-1578. https://doi.org/10.1016/j.apgeochem.2012.03.010

Matthies, R., Aplin, A., Horrocks, B., \& Mudashiru, L. (2012). Occurrence and behaviour of dissolved, nano-particulate and microparticulate iron in waste waters and treatment systems: New insights from electrochemical analysis. Journal of Environmental Monitoring, 14(4), 1173-1180. https://doi.org/10.1039/C2EM10846A

Mishra, A., \& Tripathi, B. (2008). Utilization of fly ash in adsorption of heavy metals from wastewater. Environmental Toxicology and Chemistry, 90(6), 1091-1097. https:// doi.org/10.1080/02772240801936786

Mitsch, W., Zhang, L., Stefanik, K., Nahlik, A., Anderson, C., Bernal, B., Hernandez, M., \& Song, K. (2012). Creating wetlands: Primary succession, water quality changes, and self-design over 15 years. BioScience, 62(3), 237-250. https://doi.org/10.1525/bio.2012.62.3.5

Mitsch W, Gosselink J, (2000) Wetlands (5th ed.). John Wiley $\&$ Sons.

Neculita, C., \& Rosa, E. (2019). A review of the implications and challenges of manganese removal from mine drainage. Chemosphere, 214, 491-510. https://doi.org/10. 1016/j.chemosphere.2018.09.106

Nyquist, J., \& Greger, M. (2009). A field study of constructed wetlands for preventing and treating acid mine drainage. Ecological Engineering, 35(5), 630-642. https://doi.org/ 10.1016/j.ecoleng.2008.10.018

Opitz, J., Alte, M., Bauer, M., \& Peiffer, S. (2020). Quantifying iron removal efficiency of a passive mine water treatment system using turbidity as a proxy for (particulate) iron. Applied Geochemistry, 120, 104731. https://doi.org/10. 1016/j.apgeochem.2020.104731

Opitz, J., Alte, M., Bauer, M., \& Peiffer, S. (2021). The role of macrophytes in constructed surface-flow wetlands for mine water treatment: A review. Mine Water and the Environment, 40(3), 587-605. https://doi.org/10.1007/ s10230-021-00779-X

Opitz J, Alte M, Bauer M, Peiffer S (2019) Testing iron removal in a trifurcated pilot plant for passive treatment of circumneutral ferruginous mine water. In: Proc. IMWA 2019 Conf., Perm (Russia), 256-262.

Park, J., Han, Y., \& Ahn, J. (2016). Comparison of arsenic co-precipitation and adsorption by iron minerals and the mechanism of arsenic natural attenuation in a mine stream. Water Research, 106(1), 295-303. https://doi.org/ 10.1016/j.watres.2016.10.006

Pfannkuche, J., \& Schmidt, A. (2003). Determination of suspended particulate matter concentration from turbidity measurements: Particle size effects and calibration procedures. Hydrological Processes, 17(10), 1951-1963. https://doi.org/10.1002/hyp.1220

Sapsford, D. J. (2013). New perspectives on the passive treatment of ferruginous circumneutral mine waters in the UK. Environmental Science and Pollution Research, 20(11), 7827-7836. https://doi.org/10.1007/s11356-013-1737-3 
Sapsford, D., \& Watson, I. (2011). A process-orientated design and performance assessment methodology for passive mine water treatment systems. Ecological Engineering, 37(6), 970-975. https://doi.org/10.1016/j.ecoleng.2010. 12.010

Schaider, L., Senn, D., Estes, E., Brabander, D., \& Shine, J. (2014). Sources and fates of heavy metals in a miningimpacted stream: Temporal variability and the role of iron oxides. Science of the Total Environment, 490, 456-466. https://doi.org/10.1016/j.scitotenv.2014.04.126

Schieferstein, B. (1999). Ecological and molecular biological investigations on reed (Phragmites australis (Cav.) Trin. ex Steudel) in lakes of northern Germany - An overview. Limnologica, 29(1), 28-35. https://doi.org/10.1016/s00759511(99)80036-x

Silva, A., Cruz, F., Lima, R., Teixeira, M., \& Leão, V. (2010). Manganese and limestone interactions during mine water treatment. Journal of Hazardous Materials, 181(1-3), 514-520. https://doi.org/10.1016/j.jhazmat.2010.05.044

Skousen, J., Zipper, C., Rose, A., Ziemkiewicz, P., Nairn, R., McDonald, L., \& Kleinmann, R. (2017). Review of passive systems for acid mine drainage treatment. Mine Water and the Environment, 36(1), 133-153. https://doi.org/10. 1007/s10230-016-0417-1

Sobolewski, A. (1999). A review of processes responsible for metal removal in wetlands treating contaminated mine drainage. International Journal of Phytoremediation, 1(1), 19-51. https://doi.org/10.1080/15226519908500003

Stark, L., Williams, F., Wenerick, W., Wuest, P., \& Urban, C. (1996). The effects of substrate type, surface water depth, and flow rate on manganese retention in mesocosm wetlands. Journal of Environmental Quality, 25(1), 97-106. https://doi.org/10.2134/jeq1996.00472425002500010013 $\mathrm{x}$

Stumm W; Morgan J (1996) Aquatic chemistry: Chemical equilibria and rates in natural waters (3rd ed.). John Wiley $\&$ Sons.

Tan, H., Zhang, G., Heaney, P. J., Webb, S., \& Burgos, W. (2010). Characterization of manganese oxide precipitates from Appalachian coal mine drainage treatment systems. Applied Geochemistry, 25(3), 389-399. https://doi.org/10. 1016/j.apgeochem.2009.12.006

Tebo, B., Bargar, J., Clement, B., Dick, G., Murray, K., Parker, D., Verity, R., \& Webb, S. (2004). Biogenic manganese oxides: Properties and mechanisms of formation. Annual
Review of Earth and Planetary Sciences, 32, 287-328. https://doi.org/10.1146/annurev.earth.32.101802.120213

Trumm, D. (2010). Selection of active and passive treatment systems for AMD - Flow charts for New Zealand conditions. New Zealand Journal of Geology and Geophysics, 53(2-3), 195-210. https://doi.org/10.1080/00288306. 2010.500715

Vymazal, J. (2013). The use of hybrid constructed wetlands for wastewater treatment with special attention to nitrogen removal: A review of a recent development. Water Research, 47(14), 4795-4811. https://doi.org/10.1016/j. watres.2013.05.029

Vymazal, J. (2014). Constructed wetlands for treatment of industrial wastewaters: A review. Ecological Engineering, 73, 724-751. https://doi.org/10.1016/j.ecoleng.2014.09. 034

Whitehead, P., \& Prior, H. (2005). Bioremediation of acid mine drainage: An introduction to the Wheal Jane wetlands project. Science of the Total Environment, 338(1-2), 15-21. https://doi.org/10.1016/j.scitotenv.2004.09.016

Wildemann T, Brodie G, Gusek, J., (1993). Wetland design for mining operations. BiTech Publishers.

Younger, P. (2000a). The adoption and adaptation of passive treatment technologies for mine waters in the United Kingdom. Mine Water and the Environment, 19(2), 84-97. https://doi.org/10.1007/BF02687257

Younger, P. (2000b). Holistic remedial strategies for short- and long-term water pollution from abandoned mines. Mining Technology, 109(3), 210-2018. https://doi.org/10.1179/ mnt.2000.109.3.210

Zänker, H., Richter, W., \& Hüttig, G. (2003). Scavenging and immobilization of trace contaminants by colloids in the waters of abandoned ore mines. Colloids and Surfaces A, 217(1), 21-31. https://doi.org/10.1016/S0927-7757(02) 00555-1

Ziemkiewicz, P., Skousen, J., \& Simmons, J. (2003). Longterm performance of passive acid mine drainage treatment systems. Mine Water and the Environment, 22(3), 11a8129. https://doi.org/10.1007/s10230-003-0012-0

Publisher's Note Springer Nature remains neutral with regard to jurisdictional claims in published maps and institutional affiliations. 